\title{
Application of the Rules of Corporate Governance on Accounting Disclosure and Quality of Financial Reports in Commercial banks in Khartoum Stock Exchange
}

\author{
Elzain Omer Elzain \\ CBE, Accounting Department, Qassim University, Saudi Arabia
}

Correspondence Author: Elzain Omer Elzain, CBE, Accounting Department Qassim University, Saudi Arabia. Email: elzain1976a@hotmail.com

Received date: 15 June 2019, Accepted date: 22 August 2019, Online date: 29 August 2019

Copyright: () 2019 Elzain Omer Elzain, This is an open-access article distributed under the terms of the Creative Commons Attribution License, which permits unrestricted use, distribution, and reproduction in any medium, provided the original author and source are credited.

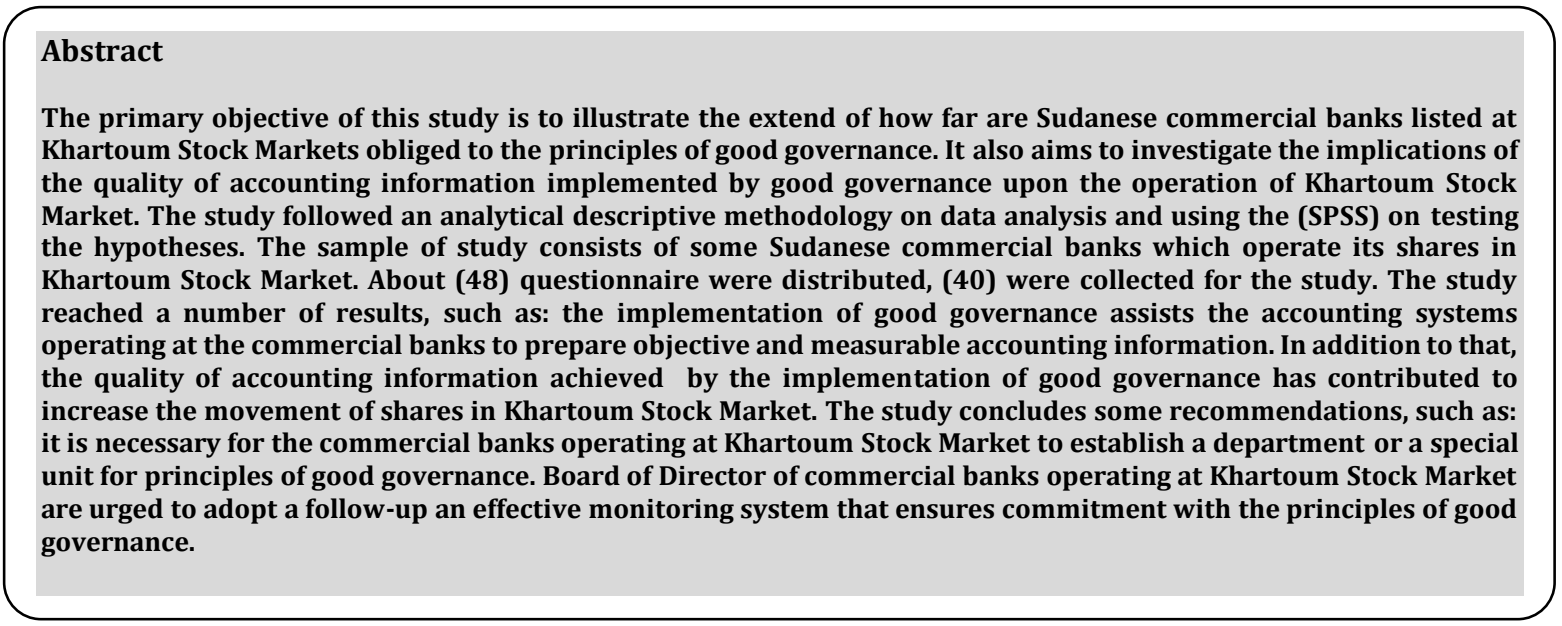

Keywords: Corporate Governance, Accounting Disclosure, Commercial banks in Khartoum Stock Exchange

\section{INTRODUCTION}

The success of corporate governance leads to success and encouragement of investment and the improvement of economic and financial stability from the social aspects. It also assists in the development of all stakeholders with the company and enhancing the socio-environmental conditions. It also contributes to preventing corruption in accounting operations and affects the market values of the company's shares. This happens through government intervention in monitoring companies and protecting small investors and other stakeholders. (Annual Report, issued by The Academic Symposium on Good Governance, 2017).

The importance of the term, corporate governance, increased in all institutions and in all advanced and emerging economies in the last few decades especially after the economic and financial crisis that many countries underwent. These crisis affected the global financial market; such as the crisis in Southeast Asia in 1997. Moreover, many major international companies especially the American companies collapsed in Fall 2008 because they used complex accounting methods in order to hide theirs loses and manipulate the rights of people; such as shareholders, lenders, suppliers, and even the civil society. Hence, governance became one of the important topics that are applied in both privet and public companies, (Munadhil, Honer and Ali (2018).

The international institutions were very keen to address the issue of corporate governance and its applications. These institutions included the International Monetary Fund (IMF), the World Bank and the Organization for Economic Co-operation and Development (OECD), which issued in 1999 the principles of corporate governance by providing a number of guidelines, which will support the management of companies and the efficiency of financial markets.

It is also possible that one of the most important reasons that led to the collapse of many economic units is the lack of disclosure and transparency and the lack of real financial data and information. This, in turn, has led to many negative effects, the 
Citation: Elzain Omer Elzain, Application of the Rules of Corporate Governance on Accounting Disclosure and Quality of Financial Reports in Commercial banks in Khartoum Stock Exchange. Australian Journal of Basic and Applied Sciences, 13(8): 95-103. DOI: 10.22587/ajbas.2019.13.8.13

most important of which is the loss of confidence in the accounting information, which in turn had reflected on the quality of this information.

The financial market in Sudan is still less developed and so we need efforts to increase the investors' confidence level. The corporate governance so should be activated and it should also be sufficient to reduce the corruption level.

In fact, despite the production of oil since 2000, in addition to many other sources of national wealth, Sudan is classified, according to many international organizations, amongst the very poor and most corrupt countries in the world (CPI, 2017; Economic Freedom Index, 2016, World Bank, 2017), (Elnafabi, 2019).

The problem of the study was in the following central question: What is the impact of the application of corporate governance rules on the accounting disclosure and quality of financial reports of commercial banks listed on Khartoum Stock Exchange? This study aimed to achieve the following objectives: first, to identify the extent of the commitment of the Sudanese banks listed on Khartoum Stock Exchange to apply the principles of corporate governance. Second, learn how to use the principles of corporate governance in improving the quality of accounting information.

\section{Previous studies}

(Abu Hammam, 2009) Stated that the quality of accounting information and its impact on the rules of governance. The study used the descriptive-analytical method. The study found that the application of governance rules had contributed significantly to enhance the role of accounting disclosure and quality of financial reporting. The study recommended that deepening concepts and complying with the regulations led down by the Organization for Economic Co-operation and Development through holding the necessary training courses and working to follow up the modernization and development of the proper application of the rules of governance.

(Aqeel, 2011) Reported that the measurement of the quality of the accounting information contained in the annual financial reports issued by the Saudi joint-stock companies by applying to a sample of the Saudi companies participating during the period 1991 - 2009. The results of the study showed that the accounting information contained in the annual financial reports issued by Saudi joint-stock companies (Such as Germany, France and Japan) were lower than those in the common law markets (USA, UK, and Australia) and that there was an increase in the rate of negative income change and the absence of a statistical significance relationship to the positive changes in income between the current year and the preceding year for the period following the establishment of the Capital Market Authority compared to the period prior to its establishment, indicating that the joint-stock companies were more committed to recognizing potential losses immediately and post ponding Potential earnings until they actually happen. The study recommended that users of financial statements should be aware of the importance of the quality of accounting information in assessing the company's ability to generate future cash flows.

(Imam, 2014) Found that there was a relationship between the application of the principles of corporate governance and the quality of accounting information. The study concluded that the implementation of the principles of corporate governance led to the production of accounting information with the specific characteristics of data. The application of corporate governance principles contributes to the provision of appropriate information to make investment decisions in Khartoum Stock Exchange, thus reducing the risk of investment in the market. The study recommended that the listed companies in Khartoum Stock Exchange should establish a department or specific section for the principles and standards of corporate governance in each bank.

\section{MATERIALS AND METHODS}

The questionnaire consisted of the following: The first axis includes information or personal variables related to the sample members of the study, gender, scientific qualification, scientific specialization, professional qualification, number of years of experience, career status. The second axis includes the central hypothesis of the study. The questionnaire form is based on the closed-form using the five-point Likert scale of the responses respectively $(1,2,3,4,5)$.

\section{RESULTS}

Table 1: The statistical range of responses related to the second part of the questionnaire

\begin{tabular}{|c|c|}
\hline Response & Range of The Responses \\
\hline Strongly Agree & $1-1.8$ \\
\hline Agree & $1.9-2.6$ \\
\hline Not Sure & $2.7-3.4$ \\
\hline Disagree & $3.5-4.2$ \\
\hline Strongly Disagree & $4.3-5$ \\
\hline
\end{tabular}

Source: Prepared by the researcher from the questionnaire data, 2018.

Table 1. Showed that the Strongly Agree ranged between 1-1.8, Agree 1-9-2.6, Not sure 2.7-3.4, Disagree 3.5-4.2, and for those Strongly Disagree was in the range of 4.3-5. 
Table 2: Pearson correlation coefficients between hypothesis Items

\begin{tabular}{|c|c|c|c|c|c|c|c|}
\hline \multicolumn{3}{|c|}{ First hypothesis } & \multicolumn{3}{c|}{ Second hypothesis } & \multicolumn{2}{c|}{ Third hypothesis } \\
\hline Item & Correlation Coefficient Item & Correlation Coefficient & \multicolumn{1}{|c|}{ Correlation Coefficient Item Correlation Coefficient } \\
\hline 1 & 0.664 & 1 & 0.685 & 11 & 0.714 & 1 & 0.554 \\
\hline 2 & 0.704 & 2 & 0.589 & 12 & 0.682 & 2 & 0.622 \\
\hline 3 & 0.696 & 3 & 0.520 & 13 & 0.559 & 3 & 0.655 \\
\hline 4 & 0.656 & 4 & 0.570 & 14 & 0.631 & 4 & 0.718 \\
\hline 5 & 0.758 & 5 & 0.612 & 15 & 0.679 & 5 & 0.723 \\
\hline 6 & 0.803 & 6 & 0.600 & 16 & 0.675 & 6 & 0.755 \\
\hline 7 & 0.665 & 7 & 0.708 & 17 & 0.602 & 7 & 0.802 \\
\hline 8 & 0.713 & 8 & 0.552 & 18 & 0.705 & - & - \\
\hline- & - & 9 & 0.612 & 19 & 0.811 & - & - \\
\hline- & - & 10 & 0.667 & - & - & - & - \\
\hline
\end{tabular}

Source: Prepared by researcher from the questionnaire data, 2018.

Table 2. Showed that there was a strong and positive correlation between the terms of each hypothesis and the hypothesis to which it belonged, which gives the highest credibility to the construction of the study tools. This indicates that the internal consistency between all the hypotheses of the study.

Table 3: Frequency distribution of age

\begin{tabular}{|c|c|c|c|}
\hline No & Age & Frequency & Percentage \\
\hline 1 & Less than 30 year & 5 & $12.5 \%$ \\
\hline 2 & $30-35$ year & 7 & $17.5 \%$ \\
\hline 3 & $36-40$ year & 14 & $35 \%$ \\
\hline 4 & 41-45 year & 5 & $12.5 \%$ \\
\hline 5 & 46-50 year & 5 & $12.5 \%$ \\
\hline 6 & More than 50 year & 4 & $10 \%$ \\
\hline & Total & 40 & $100 \%$ \\
\hline
\end{tabular}

Source: Prepared by a researcher from the questionnaire data, 2018.

Table 3. Showed that the majority of the sample age ranged from 30-35 years of age was $17.5 \%$, 36 - 40 years of age $35 \%$, among those aged between 41 - 45 years of age $12.5 \%, 46$ - 50 years of age was $12.5 \%$, 50 years and above was $10 \%$ and for less than 30 years was $12.5 \%$.

Table 4: Frequency distribution of Qualifications

\begin{tabular}{|c|c|c|c|}
\hline No & Qualifications & Frequency & Percentage \\
\hline 1 & BA & 25 & $62.5 \%$ \\
\hline 2 & Higher Diploma & 6 & $15 \%$ \\
\hline 3 & M.A. & 8 & $20 \%$ \\
\hline 4 & Ph. D & 1 & $2.5 \%$ \\
\hline \multicolumn{2}{|c|}{ Total } & 40 & $100 \%$ \\
\hline
\end{tabular}

Source: Prepared by the researcher from the questionnaire data, 2018.

Table 4. Showed that the holders of a Bachelor's degree are the majority (62.5\%), Higher Diploma (15\%), M.A (20\%), and $\mathrm{PhD}(2.5 \%)$. Therefore the majority of qualified staff members are those were holding BA Degree.

Table 5: Frequency distribution of Scientific Specialization

\begin{tabular}{|c|c|c|c|}
\hline No & Scientific specialization & Frequency & Percentage \\
\hline 1 & Accounting & 17 & $42.5 \%$ \\
\hline 2 & costs \& costs and accounting & 3 & $7.5 \%$ \\
\hline 3 & Business Administration & 7 & $17.5 \%$ \\
\hline 4 & Economic & 11 & $27.5 \%$ \\
\hline 5 & Banking and financial studies & 2 & 5 \\
\hline 6 & Information Systems & 0 & 0 \\
\hline \multicolumn{2}{r|}{ Total } & 40 & $100 \%$ \\
\hline
\end{tabular}

Source: Prepared by researcher from the questionnaire data, 2018. 
Citation: Elzain Omer Elzain, Application of the Rules of Corporate Governance on Accounting Disclosure and Quality of Financial Reports in Commercial banks in Khartoum Stock Exchange. Australian Journal of Basic and Applied Sciences, 13(8): 95-103. DOI: 10.22587/ajbas.2019.13.8.13

Table 5. Showed that the scientific specialization is accounting and funding their proportion of (42.5\%) of the sample of the study, and that they allocate administrative costs and accounting (7.5\%), while those who specialized in business management (17.5\%), Economic (27.5\%), specialized banking and financial studies (5\%), and that there was no specialization of information systems, the highest percentage was those specialized in accounting.

Table 6: Frequency distribution of Qualification

\begin{tabular}{|c|c|c|c|}
\hline No & Qualification & Frequency & Percentage \\
\hline 1 & Sudanese Fellowship SCA & 26 & $25 \%$ \\
\hline 2 & Arab Fellowship ACPA & 4 & $10 \%$ \\
\hline 3 & British Fellowship ACCA & 8 & $20 \%$ \\
\hline 4 & American Fellowship AICPA & 2 & $5 \%$ \\
\hline \multicolumn{2}{|c|}{ Total } & 40 & $100 \%$ \\
\hline
\end{tabular}

Source: Prepared by the researcher from the questionnaire data, 2018.

Table 6. Showed that the majority of the sample of the study obtained the qualification of practising the profession, was the Sudanese Fellowship (SCA) (65\%), Arab Fellowship ACPA (10\%), British Fellowship (ACCA) (20\%), and the American Fellowship (AICPA) (5\%). The highest proportion of their professional qualification was the Sudanese Fellowship.

Table 7: Frequency distribution Years of Experience

\begin{tabular}{|c|c|c|c|}
\hline No & Years of Experience & Frequency & Percentage \\
\hline 1 & Less than 5 Years & 10 & $25 \%$ \\
\hline 2 & 6-10 Years & 13 & $32.5 \%$ \\
\hline 3 & $11-15$ Years & 5 & $12.5 \%$ \\
\hline 4 & $16-20$ Years & 6 & $15 \%$ \\
\hline 5 & More than 20 Years & 6 & $15 \%$ \\
\hline \multicolumn{2}{|c|}{ Total } & 40 & $100 \%$ \\
\hline
\end{tabular}

Source: Prepared by the researcher from the questionnaire data, 2018.

Table 7. showed that those who have years of experience 5 years or less (25\%), 6-10 Years (32.5\%), 11-15 Years (12.5\%), 16-20 Years (15\%), and More than 20 Years (15\%). Therefore the expert staff members were the majority (6-10 years).

Table 8: Job status

\begin{tabular}{|c|c|c|c|}
\hline No & Job status & Frequency & Percentage \\
\hline 1 & Accountant & 20 & $50 \%$ \\
\hline 2 & Head of the Department & 11 & $27.5 \%$ \\
\hline 3 & Financial Controller & 2 & $5 \%$ \\
\hline 4 & Financial Manager & 4 & $10 \%$ \\
\hline 5 & Financial Analyst & 1 & $2.5 \%$ \\
\hline 6 & Securities Agent & 1 & $2.5 \%$ \\
\hline 7 & Checker & 1 & $2.5 \%$ \\
\hline & Total & 40 & $100 \%$ \\
\hline
\end{tabular}

Source: Prepared by the researcher from the questionnaire data, 2018.

Table 8. Showed that the accountant's job was accounting (50\%), heads of departments $(27.5 \%)$, financial observers $(5 \%)$, financial managers $(10 \%)$, financial analysts $(\%(2.5 \%)$, securities agents $(2.50 \%)$, and Checkers $(2.5 \%)$. The highest percentage of accountants was the majority.

\section{Hypothesis Test}

The First hypothesis: that there was a statistically significant relationship between the application of the principles of corporate governance and the quality of accounting information.

Table 9: The arithmetic mean and the standard deviation of the first hypothesis

\begin{tabular}{|c|c|c|c|c|c|c|c|c|c|}
\hline \multirow[b]{2}{*}{ No } & \multirow[b]{2}{*}{ Statement } & 1 & 2 & 3 & 4 & 5 & \multirow[b]{2}{*}{ Mean } & \multirow{2}{*}{$\begin{array}{l}\text { Standard } \\
\text { Deviation }\end{array}$} & \multirow[b]{2}{*}{$\begin{array}{l}\text { Chi- } \\
\text { Square }\end{array}$} \\
\hline & & $\begin{array}{c}\text { Strongly } \\
\text { Agree }\end{array}$ & Agree & $\begin{array}{l}\text { Not } \\
\text { Sure }\end{array}$ & Disagree & $\begin{array}{l}\text { Strongly } \\
\text { Disagree }\end{array}$ & & & \\
\hline 1 & $\begin{array}{c}\text { Application of corporate governance principles leads } \\
\text { to the disclosure of high-accuracy accounting } \\
\text { information. }\end{array}$ & 11 & 26 & 3 & 0 & 0 & 1.80 & 0.56 & 0.77 \\
\hline 2 & $\begin{array}{l}\text { Commitment to applying corporate governance } \\
\text { principles leads to the processing of objective }\end{array}$ & 14 & 21 & 5 & 0 & 0 & 1.78 & 0.66 & 0.78 \\
\hline
\end{tabular}


Citation: Elzain Omer Elzain, Application of the Rules of Corporate Governance on Accounting Disclosure and Quality of Financial Reports in Commercial banks in Khartoum Stock Exchange. Australian Journal of Basic and Applied Sciences, 13(8): 95-103. DOI: 10.22587/ajbas.2019.13.8.13

\begin{tabular}{|c|c|c|c|c|c|c|c|c|c|}
\hline & information & & & & & & & & \\
\hline & $\begin{array}{c}\text { Commitment to applying corporate governance } \\
\text { principles helps to provide accounting information in } \\
\text { a timely manner (temporary information) }\end{array}$ & 16 & 20 & 3 & 1 & 0 & 1.73 & 0.72 & 0.79 \\
\hline 4 & $\begin{array}{c}\text { Provide comprehensive accounting information due } \\
\text { to compliance with the principles of corporate } \\
\text { governance }\end{array}$ & 11 & 24 & 5 & 0 & 0 & 1.85 & 0.62 & 0.76 \\
\hline 5 & $\begin{array}{l}\text { The clarity of accounting information is linked to the } \\
\text { obligation to apply corporate governance principles }\end{array}$ & 13 & 18 & 4 & 4 & 1 & 2.05 & 1.04 & 0.73 \\
\hline 6 & $\begin{array}{l}\text { Application of corporate governance principles leads } \\
\text { to the production of flexible accounting information }\end{array}$ & 12 & 23 & 3 & 1 & 1 & 1.90 & 0.84 & 0.75 \\
\hline 7 & $\begin{array}{c}\text { There is a positive relationship between appropriate } \\
\text { accounting information and application of corporate } \\
\text { governance principles }\end{array}$ & 12 & 26 & 1 & 1 & 0 & 1.78 & 0.62 & 0.78 \\
\hline 8 & $\begin{array}{l}\text { Application of the principles of corporate } \\
\text { governance helps the accounting system of the } \\
\text { company to prepare accounting information that is } \\
\text { measurable. }\end{array}$ & 13 & 23 & 3 & 0 & 1 & 1.83 & 0.78 & 0.77 \\
\hline \multicolumn{7}{|c|}{ Mean \& Standard Deviation in General } & \begin{tabular}{|l|}
0.73 \\
\end{tabular} & 1.84 & \\
\hline
\end{tabular}

Source: Prepared by a researcher from the SPSS, 2018

Table 9. Showed that the trends of the sample of the study were positive with a mean average (1.84) that was a statistical significant relationship between the application of the principles of corporate governance and the quality of the accounting information, which means that the main hypothesis is correct. As for the general standard deviation, it is 0.73 , ie, the concentration of the responses around the arithmetic mean. There is also a variance for the answers to (1): the arithmetic mean is (1.80) of (5) This is an acceptable answer given that the arithmetic average is less than (2.6), which is the average measurement tool, and belonged to the second category corresponding to agree, which means that "the company's application of the principles of corporate governance leads to the disclosure of high-accuracy accounting information." Phrase (2): The arithmetic mean (1.78) which was acceptable given that the arithmetic average is lower than the mean of the measuring instrument (2.6). The first category is strongly agree, which means that "The Company's commitment to apply corporate governance principles helps to provide timely accounting information (temporary information)." (4): The arithmetic average (1.85), which is acceptable as the arithmetic average is less than (2.6) and belonged to the second category corresponding to agree, which means: "Providing accounting information that is comprehensive due to the commitment to apply the principles of corporate governance." (5): the arithmetic average (2.05), which is acceptable as the arithmetic average is less than 2.6 and belongs to the second category corresponding to agree, which means: "The clarity of the accounting information is linked to the commitment to apply the principles of corporate governance. Question (6): The arithmetic average (1.90), which is acceptable as the arithmetic average is less than (2.6) and belongs to the second category corresponding to agree, which means: "Application of the principles of corporate governance leads to the production of flexible accounting information." (7): the arithmetic average (1.78), which was acceptable as the arithmetic average was less than (2.6) and belonged to the second category corresponding to agree, which means: "There was a positive relationship between the appropriate accounting information and the application of the principles of corporate governance." (8): the arithmetic average (1.83), which was acceptable giving that the arithmetic average is less than (2.6) and The second category corresponds to agree, which means: "The application of the principles of corporate governance helps the accounting system of the company to prepare measurable accounting information."

The second hypothesis: Implementing the principles of corporate governance increases the quality of accounting information.

Table 10: The arithmetic mean and the standard deviation of the second hypothesis

\begin{tabular}{|c|c|c|c|c|c|c|c|c|c|}
\hline \multirow[b]{2}{*}{ No } & \multirow[b]{2}{*}{ Statement } & $\mathbf{1}$ & 2 & 3 & 4 & 5 & \multirow[b]{2}{*}{ Mean } & \multirow[b]{2}{*}{$\begin{array}{l}\text { Standard } \\
\text { Deviation }\end{array}$} & \multirow[b]{2}{*}{$\begin{array}{l}\text { Chi- } \\
\text { Square }\end{array}$} \\
\hline & & $\begin{array}{l}\text { Strongly } \\
\text { Agree }\end{array}$ & Agree & $\begin{array}{c}\text { Not } \\
\text { Sure }\end{array}$ & Disagree & $\begin{array}{l}\text { Strongly } \\
\text { Disagree }\end{array}$ & & & \\
\hline 1 & $\begin{array}{c}\text { Your company protects shareholders' rights by } \\
\text { providing means for registering and transferring } \\
\text { equity. }\end{array}$ & 18 & 14 & 8 & 0 & 0 & 1.75 & 0.78 & 0.78 \\
\hline 2 & $\begin{array}{c}\text { Contributors get different information about your } \\
\text { company easily. }\end{array}$ & 13 & 23 & 3 & 1 & 0 & 1.80 & 0.69 & 0.77 \\
\hline 3 & $\begin{array}{c}\text { Your company protects shareholders' rights by } \\
\text { allowing them to attend the General Assembly and } \\
\text { vote }\end{array}$ & 18 & 17 & 5 & 0 & 0 & 1.68 & 0.69 & 0.80 \\
\hline 4 & Your shareholders get their rights to profits & 22 & 14 & 3 & 1 & 0 & 1.58 & 0.75 & 0.81 \\
\hline 5 & Your company is committed to the principle of & 20 & 17 & 2 & 0 & 1 & 1.63 & 0.81 & 0.80 \\
\hline
\end{tabular}


Citation: Elzain Omer Elzain, Application of the Rules of Corporate Governance on Accounting Disclosure and Quality of Financial Reports in Commercial banks in Khartoum Stock Exchange. Australian Journal of Basic and Applied Sciences, 13(8): 95-103. DOI: 10.22587/ajbas.2019.13.8.13

\begin{tabular}{|c|c|c|c|c|c|c|c|c|c|}
\hline & $\begin{array}{l}\text { equality between the shareholders of the transaction } \\
\text { through the provision of information to the various } \\
\text { categories of beneficiaries }\end{array}$ & & & & & & & & \\
\hline 6 & $\begin{array}{c}\text { All shareholders of the same category are treated } \\
\text { equally }\end{array}$ & 16 & 21 & 2 & 0 & 1 & 1.73 & 0.78 & 0.79 \\
\hline 7 & $\begin{array}{l}\text { There is equality between the shareholders of the } \\
\text { transaction by defending their legal rights. }\end{array}$ & 20 & 18 & 1 & 0 & 1 & 1.70 & 0.78 & 0.81 \\
\hline 8 & $\begin{array}{c}\text { Shareholders shall have access to disclosure } \\
\text { procedures for the interests of the Board of Directors } \\
\text { and Directors of the Company }\end{array}$ & 14 & 15 & 11 & 0 & 0 & 1.93 & 0.80 & 0.75 \\
\hline 9 & $\begin{array}{c}\text { Effective mechanisms and means of compensation are } \\
\text { available to protect the rights of shareholders in case } \\
\text { of infringement of their rights }\end{array}$ & 14 & 19 & 7 & 0 & 0 & 1.83 & 0.71 & 0.77 \\
\hline 10 & $\begin{array}{c}\text { Cooperation between stakeholders and management } \\
\text { of the company }\end{array}$ & 12 & 23 & 5 & 0 & 0 & 1.83 & 0.64 & 0.77 \\
\hline 11 & $\begin{array}{l}\text { There is a role for stakeholders in the company } \\
\text { through participation in monitoring and monitoring } \\
\text { the performance of the company }\end{array}$ & 13 & 18 & 7 & 2 & 14 & 1.95 & 0.85 & 0.74 \\
\hline 12 & $\begin{array}{c}\text { Ensuring that stakeholders have access to adequate, } \\
\text { adequate and reliable information }\end{array}$ & 12 & 23 & 4 & 1 & 0 & 1.85 & 0.70 & 0.76 \\
\hline 13 & $\begin{array}{c}\text { Your company is committed to the principle of } \\
\text { disclosure and transparency through the accuracy of } \\
\text { disclosure. }\end{array}$ & 13 & 25 & 1 & 1 & 0 & 1.75 & 0.63 & 0.78 \\
\hline 14 & $\begin{array}{l}\text { The published information shall be disclosed } \\
\text { transparently, taking into account the appropriate } \\
\text { timing of disclosure. }\end{array}$ & 17 & 19 & 4 & 0 & 0 & 1.68 & 0.66 & 0.80 \\
\hline 15 & $\begin{array}{c}\text { The Company is committed to the principle of } \\
\text { comprehensive disclosure of accounting information }\end{array}$ & 16 & 13 & 8 & 2 & 1 & 1.98 & 1.03 & 0.74 \\
\hline 16 & $\begin{array}{c}\text { The company provides access channels for accounting } \\
\text { information to users. }\end{array}$ & 15 & 18 & 7 & 0 & 0 & 2.05 & 0.96 & 0.77 \\
\hline 17 & $\begin{array}{c}\text { The Board of Directors is working to ensure that it is } \\
\text { accountable to the Company and its shareholders }\end{array}$ & 18 & 17 & 2 & 2 & 1 & 1.78 & 1.62 & 0.78 \\
\hline $18{ }^{\mathrm{t}}$ & $\begin{array}{l}\text { The Board of Directors of the Company shall abide by } \\
\text { the laws and regulations and shall strive to achieve the } \\
\text { interests of all parties concerned with the Company. }\end{array}$ & 17 & 16 & 5 & 1 & 1 & 1.83 & 0.95 & 0.77 \\
\hline 19 & $\begin{array}{l}\text { The company's board of directors makes decisions } \\
\text { and follows up the company's core functions and } \\
\text { functions }\end{array}$ & 17 & 17 & 7 & 3 & 0 & 1.90 & 0.96 & 0.75 \\
\hline \multicolumn{7}{|c|}{ Mean \& Standard Deviation in General } & 1.78 & 0.78 & - \\
\hline
\end{tabular}

Source: Prepared by the researcher from the SPSS, 2018.

Table (10) showed that the trends of the sample of the research sample were positive and acceptable to all the statements related to the second hypothesis, where the general average (1.78) was the average falls within the first category of Likert scale (1.8), which was strongly agreed, Members of the study sample agree that (applying the principles of corporate governance increases the quality of accounting information), which means proving the second hypothesis. The value of the calculated Chisquare for all the second hypothesis terms was significantly greater than the value of alpha $(<=0.05 \alpha)$ for all expressions, confirming a strong statistical relationship and thus proving the second hypothesis. The general standard deviation was (0.78) This means that the responses of the sample as a whole are somewhat centred around their arithmetic mean. It is also clear from the results of the table that there is a discrepancy in the sample answers to the terms of the first hypothesis as follows: The Statement (1): the arithmetic average is 1.75 of 5 , which is acceptable because the mean is less than (2.6) The instrument of measurement also belongs to the first category corresponding to the strongly agreed, which means the following: "The company protects the rights of shareholders by providing means of recording and transferring ownership of Statement (2): The arithmetic mean is 1.80 of 5, which is acceptable because the mean is less than the average of the measurement instrument and belongs to the second category corresponding to agree. This means: "The shareholders obtain the various information related to the company easily Statement (3): The average arithmetic mean (1.68) of (5), which is acceptable as the arithmetic average is less than (2.6) and belongs to the first category corresponding to the strongly agreed which means the following: "The company protects the shareholders' rights by allowing them to attend the general assembly, Board of Directors Statement (4): The arithmetic average is 1.58, which is acceptable because the arithmetic average is less than 2.6 and belong to the first category corresponding to the strongly agreed. This means that the shareholders of the company get their rights to profits. Statement (5): The arithmetic a verage is (1.63), which is acceptable because the mean is less than (2.6) The first category of the interview is strongly agreed, meaning 
Citation: Elzain Omer Elzain, Application of the Rules of Corporate Governance on Accounting Disclosure and Quality of Financial Reports in Commercial banks in Khartoum Stock Exchange. Australian Journal of Basic and Applied Sciences, 13(8): 95-103. DOI: 10.22587/ajbas.2019.13.8.13

that "the shareholders of the company get their rights to profits. Statement (5): The arithmetic average is 1.63, which is acceptable as the arithmetic average was less than (2.6) and belong to the first category corresponding to the strongly approved means: "The company is committed to the principle of equality between the shareholders of the transaction through equal information for different categories Beneficiary ". Statement (6): The arithmetic average is 1.73, which is acceptable because the mean is less than (2.6) The first category corresponds to strongly agreed, which means: "All shareholders of the same category are treated equally" Statement (7): The arithmetic average is 1.60, which is acceptable because the mean is less than (2.6) and belong to the first category corresponding to the strongly agreed, which means: "There is equality between the shareholders of the transaction by defending their legal rights. Statement (8): The arithmetic mean is 1.93, which is acceptable because the average is less than 2.6 and belongs to the second category corresponding to agree, which means: "Shareholders are entitled to review the disclosure procedures for the interests of the board of directors and managers of the company Statement (9): The mean is 1.83, which is acceptable as the mean is lower than (2.6) and belongs to the second category corresponding to agree, which means: "Effective mechanisms and means of compensation are available to protect the rights of shareholders in case of infringement of their rights. Statement (10): The arithmetic mean is (1.83), which is acceptable because the mean is less than (2.6) and belong to the second category corresponding to agree, which means: "Cooperation between stakeholders and management of the company. Statement (11): The arithmetic average is 1.95 , which is acceptable as the arithmetic average is less than (2.6) and belong to the second category corresponding to agree, which means: "There is a role for stakeholders in the company through participation in monitoring and monitoring the performance of the company. Statement (12): The arithmetic mean is (1.85) which is an acceptable answer As the arithmetic average is less than (2.6) and belong to the second category corresponding to agree, which means: "ensuring that the stakeholders have access to adequate, adequate and reliable information". Statement (13): The arithmetic average is 1.75 , which is acceptable as the arithmetic average is less than (2.6) and belong to the first category corresponding to the strongly agreed, which means: "The company is committed to the principle of disclosure and transparency through the accuracy of disclosure. Statement (14): The arithmetic mean is (1.68), which is acceptable as the arithmetic average is less than (2.6) and belong to the first category corresponding to the strongly agreed, which means: "the published information is disclosed transparently taking into account the appropriate timing of disclosure.Statement (15): The arithmetic mean is (1.98) which is acceptable as the average Less than (2.6) and belonging to the second category corresponding to agree, which means the following "The company is committed to the principle of comprehensive disclosure of accounting information. Statement (16): The arithmetic mean is (2.05), which is acceptable as the arithmetic average is less than (2.6) and belongs to the second category corresponding to agree, which means the following: The company provides some access channels for accounting information to users. Statement (17): The arithmetic average is (1.78), which is acceptable as the arithmetic average is less than (2.6) and belong to the first category corresponding to the strongly agreed, which means "The board works to achieve the necessary degree to ensure its responsibility towards the company and the shareholders. Statement (18): The average arithmetic mean (1.83), which is acceptable as the arithmetic average is less than (2.6) and belongs to the second category corresponding to agree. This means that the board of directors is committed to laws and regulations. Statement (19): "The average arithmetic mean (1.90), This is an acceptable answer given that the arithmetic average is less than (2.6) and was belonged to the second category corresponding to agree, meaning the following: "The board of directors of the company makes decisions and follow up the basic functions and functions of the company."

The third hypothesis: the application of banks to the principles of corporate governance contributes to the provision of appropriate information to make investment decisions in the Khartoum Stock Exchange.

Table 11: The arithmetic average and the standard deviation of the third hypothesis

\begin{tabular}{|c|c|c|c|c|c|c|c|c|c|}
\hline \multirow[b]{2}{*}{ No } & \multirow[b]{2}{*}{ Statement } & 1 & 2 & 3 & 4 & 5 & \multirow[b]{2}{*}{ Mean } & \multirow[b]{2}{*}{$\begin{array}{l}\text { Standard } \\
\text { Deviation }\end{array}$} & \multirow[b]{2}{*}{$\begin{array}{c}\text { Chi } \\
\text { Square }\end{array}$} \\
\hline & & $\begin{array}{c}\text { Strongly } \\
\text { Agree }\end{array}$ & Agree & $\begin{array}{l}\text { Not } \\
\text { Sure }\end{array}$ & Disagree & $\begin{array}{l}\text { Strongly } \\
\text { Disagree }\end{array}$ & & & \\
\hline 1 & $\begin{array}{l}\text { The quality of the accounting information achieved in } \\
\text { the application of the principles of corporate } \\
\text { governance contributes to the increase in the circulation } \\
\text { of shares in the Khartoum Stock Exchange }\end{array}$ & 12 & 21 & 6 & 1 & 0 & 1.90 & 0.74 & 0.75 \\
\hline 2 & $\begin{array}{l}\text { The quality of the accounting information resulting } \\
\text { from the application of companies listed on the } \\
\text { Khartoum Stock Exchange to the principles of } \\
\text { corporate governance increases investor confidence in } \\
\text { this information }\end{array}$ & 14 & 20 & 5 & 1 & 0 & 1.83 & 0.75 & 0.77 \\
\hline 3 & $\begin{array}{l}\text { The quality of accounting information leads to the } \\
\text { determination of fair prices for listed companies on the } \\
\text { Khartoum Stock Exchange. }\end{array}$ & 12 & 21 & 6 & 1 & 0 & 1.90 & 0.74 & 0.75 \\
\hline 4 & $\begin{array}{c}\text { The accounting information achieved in the application } \\
\text { of the principles of corporate governance helps to make } \\
\text { sound investment decisions on the Khartoum Stock } \\
\text { Exchange }\end{array}$ & 12 & 21 & 6 & 1 & 0 & 1.90 & 0.74 & 0.75 \\
\hline 5 & The quality of the accounting information resulting & 8 & 23 & 7 & 1 & 1 & 2.10 & 0.84 & 0.72 \\
\hline
\end{tabular}


Citation: Elzain Omer Elzain, Application of the Rules of Corporate Governance on Accounting Disclosure and Quality of Financial Reports in Commercial banks in Khartoum Stock Exchange. Australian Journal of Basic and Applied Sciences, 13(8): 95-103. DOI: 10.22587/ajbas.2019.13.8.13

\begin{tabular}{|c|c|c|c|c|c|c|c|c|c|}
\hline & $\begin{array}{l}\text { from the commitment of listed companies in the } \\
\text { Khartoum Stock Exchange to the principles of } \\
\text { corporate governance reduces the cost of investment in } \\
\text { the market. }\end{array}$ & & & & & & & & \\
\hline 6 & $\begin{array}{l}\text { The accounting information resulting from the } \\
\text { application of the principles of corporate governance } \\
\text { increases the efficiency of the market in providing } \\
\text { accounting information to investors. }\end{array}$ & 10 & 23 & 6 & 0 & 1 & 1.98 & 0.80 & 0.74 \\
\hline 7 & $\begin{array}{c}\text { The quality of accounting information achieved in the } \\
\text { application of the principles of corporate governance } \\
\text { reduces the risk of investment in the Khartoum Stock } \\
\text { Exchange. }\end{array}$ & 10 & 26 & 2 & 2 & 0 & 1.90 & 0.71 & 0.75 \\
\hline \multicolumn{7}{|c|}{ Mean \& Standard Deviation in General } & 1.93 & 0.76 & - \\
\hline
\end{tabular}

Source: Prepared by researcher from the SPSS, 2018.

Table (11) showed that the trends of the sample of the research sample were positive and acceptable to all the statements related to the third hypothesis. The general mean (1.93) was the average of the second category of Likert scale (1.8 - 2.6) The sample of the study agree that (apply banks to the principles of corporate governance contributes to providing the appropriate information to make investment decisions in Khartoum Stock Exchange), which means proving the third hypothesis. Also, the value of the calculated Chi-square for all The terms of the third hypothesis was of great value and greater than the value of alpha $(<=0.05 \alpha)$ for all expressions, thus confirming a strong statistical relationship, thus proving the third hypothesis. As for the general standard deviation, it was 0.76, which means that the responses of the sample as a whole are somewhat centered around the arithmetic mean. It is also evident from the results of the table that there are discrepancies in the sample answers to the terms of the third hypothesis as follows: Statement (1): The arithmetic average was 1.90 of 5, which is acceptable because the arithmetic average is less than 2.6 Mean the measurement tool as it belongs to the second category corresponding to the agree, which means the following: "The quality of accounting information achieved under the application of the principles of corporate governance contributes to increasing the circulation of shares In the Khartoum Stock Exchange. Statement (2): The arithmetic average is 1.83 of (5), which is acceptable because the mean is less than the standard of the measurement instrument and belongs to the second category corresponding to agree, which means the following: The application of companies listed on the Khartoum Stock Exchange to the principles of corporate governance increases the confidence of investors in this information. Statement (3): The arithmetic mean is 1.90 of 5, which is acceptable because the arithmetic average is less than 2.6 and belongs to the second category Which corresponds to agree, which means the following: "The quality of accounting information leads to the determination of standard prices Shares listed on the Khartoum Stock Exchange companies. Statement (4): the arithmetic average was (1.90), which is an acceptable answer, as the average (2.6) and belongs to the second category corresponding to agree, which means the following: "The accounting information achieved in the application of the principles of corporate governance helps to make sound investment decisions in the Khartoum Stock Exchange. Statement (5): The arithmetic average is 2.10, which is acceptable as the arithmetic average is less than (2.6) and belongs to the second category corresponding to agree, which means the following: "The quality of the accounting information resulting from the commitment of listed companies in the Khartoum Stock Exchange to the principles of corporate governance leads to Reducing the cost of investment in the market. Statement (6): The arithmetic average is (1.98) which is acceptable as the arithmetic mean Less than (2.6) was belonged to the second category corresponding to agree, which means: "The accounting information resulting from the application of the principles of corporate governance increases the efficiency of the market in providing accounting information to investors. Statement (7): The arithmetic average is 1.90 , which is acceptable as the arithmetic average is less than (2.6) and belong to the second category corresponding to agree, which means: "The quality of accounting information achieved under the application of the principles of corporate governance reduces the risk of investment in the market Khartoum Securities ".

\section{The Main Findings of This Study Could be summarized in the following:}

1. That the application of commercial banks to the principles of corporate governance leads to the disclosure of accounting information of high accuracy is flexible, appropriate, clarity and comprehensiveness.

2. That the Application of corporate governance principles the accounting system of commercial banks helps to prepare objective and measurable accounting information.

3. Commercial banks protect the rights of shareholders by providing means of recording and transferring ownership of shares

4. That the Banks should treat all shareholders of the same category equally and allows them to review the disclosure procedures for the interests of the Board of Directors and Directors.

5. That The boards of directors of commercial banks are working to achieve the necessary degree to ensure their responsibility towards the company and shareholders, and are committed to these laws and regulations with the concern to achieve the interests of all parties related to the company.

6. The quality of the accounting information achieved in the application of the principles of corporate governance contributes to increasing the movement of shares in the Khartoum Stock Exchange. 
7. The quality of the accounting information resulting from the application of companies listed on the Khartoum Stock Exchange to the principles of corporate governance increases investor confidence in this information.

8. The quality of accounting information leads to the determination of fair prices of listed companies in the Khartoum Stock Exchange and thus helps to make sound investment decisions.

9. The accounting information achieved in the application of the principles of corporate governance reduces the risk of investment in the Khartoum Stock Exchange

10. The accounting information resulting from the implementation of the principles of corporate governance increases the efficiency of the market in providing accounting information to investors.

\section{RECOMMENDATIONS}

1. Commercial banks listed on the Khartoum Stock Exchange should establish a department or section on corporate governance principles and standards.

2. Boards of directors of commercial banks listed on the Khartoum Stock Exchange should be interested in achieving the necessary level of accountability in case of failure to apply the principles of corporate governance.

3. Board of directors of listed commercial banks in the Khartoum Stock Exchange should be interested in following up through an effective regulatory system that ensures adherence to the principles of corporate governance.

4. Khartoum Stock Exchange should monitor the application of the corporate banks to the principles of corporate governance through specialized committees in the field of corporate governance standards.

\section{REFERENCES}

Abu Hammam, (2009), Majid Ismail, "The Effect of Application of Rules of Governance on Accounting Disclosure and the Quality of Financial Reports, A Field Study on Companies Listed in the Palestine Securities Exchange", Islamic University, Deanship of Graduate Studies.

Imam (2014), Omar, "Corporate governance and its role in improving the quality of accounting information to make investment decisions in the stock markets, applied to banks listed in Khartoum Stock Exchange, unpublished Master Thesis", Bakht Al Ruda University, Faculty of Economics and Administrative Sciences.

Aqeel (2011), Mohammed Bin Sulaiman, "The Quality of Accounting Information: An Empirical Study on Saudi Joint Stock Companies during the Period (2009-1991)", Journal of Public Administration, Third Issue. Annual Report, issued by The Academic Symposium on Good Governance, Arab league, The Arab Centre for Judicial and Legal Researches, Beirut, Lebanon, 2017).

Elnafabi,2019, Hussein Mohamed, "On the effect of audit committee characteristics on corporate governance good practices index. Fresh evidence from Sudan listed firms", Australian Journal of Basic and Applied Sciences, 2019 May; 13(5): pages 55-59.

Munadhil , Honer and Ali (2018), "The Role of Corporate Governance in Achieving Accounting Information Quality", Field Study in the Mishraq Sulfur Sulfur State Co, Cihan University of Sulaimaniya, Studies and Scientific Researches Economic Edition. 